\title{
Britannia
}

http://journals.cambridge.org/BRI

Additional services for Britannia:

Email alerts: Click here

Subscriptions: Click here

Commercial reprints: Click here

Terms of use : $\underline{\text { Click here }}$

\section{A Near Life-size, Togate Bust from Chichester, West Sussex}

Miles Russell

Britannia / Volume 44 / November 2013, pp 264 - 270

DOI: 10.1017/S0068113X13000263, Published online: 03 July 2013

Link to this article: http://journals.cambridge.org/abstract_S0068113X13000263

How to cite this article:

Miles Russell (2013). A Near Life-size, Togate Bust from Chichester, West Sussex. Britannia, 44, pp 264-270 doi:10.1017/S0068113X13000263

Request Permissions : $\underline{\text { Click here }}$ 
St Joseph, J.K. 1952: 'The Avondale road', in S.N. Miller (ed.), The Roman Occupation of South-Western Scotland, Glasgow, 60-4

Smith, J. 1889: 'Cleaves Cove, Dalry, Ayrshire', Archaeological and Historical Collections Relating to Ayrshire \& Galloway 6, 1-16

Smith, J. 1894a: 'On a stone crannog in Ashgrove Loch near Stevenston', Archaeological and Historical Collections Relating to Ayrshire \& Galloway 7, 56-61

Smith, J. 1894b 'The Ardrossan shell-mound, with an account of its excavation', Archaeological and Historical Collections Relating to Ayrshire \& Galloway 7, 62-76

Smith, J. 1895: Prehistoric Man in Ayrshire, London

Smith, J. 1919: 'Excavation of the forts of Castlehill, Aitnock, and Coalhill, Ayrshire', Proceedings of the Society of Antiquaries of Scotland 53 (1918-19), 123-34

Snape, M.E. 1993: Roman Brooches from North Britain: A Classification and a Catalogue of Brooches from Sites on the Stanegate, BAR British Series 235, Oxford

Wilson, A. 1995: 'Roman penetration in Strathclyde south of the Antonine Wall. Part one: the topographical framework', Glasgow Archaeological Journal 19 (1994-5), 1-30

Wilson, A. 2010: Roman and Native in the Central Scottish Borders, BAR British Series 519, Oxford

\begin{abstract}
A Near Life-size, Togate Bust from Chichester, West Sussex. Miles Russell writes: The purpose of this note is to draw attention to an important piece of Romano-British sculpture which, although briefly published in the USA, ${ }^{68}$ remains largely unknown (and unpublished) in Britain (FIG. 9). The significance, associations and potential context of the sculpture, therefore, have yet to be considered from a Romano-British perspective. The sculpture was purchased by the Art Museum, Princeton University in $1943^{69}$ from New York art dealer Joseph Brummer. ${ }^{70}$ It is not known how Brummer came to be in possession of the piece, but the acquisitions card, prepared at the time by curator Frances Follin Jones, records that it had originally been excavated from 'the garden of Wycombe House, Chichester in Sussex', southern England at some point in the early 1900s..$^{71}$ The whereabouts of the bust in the forty years between its initial discovery and subsequent sale to Princeton University remain unknown, although the artefact appears to have come into the USA just prior to the Second World War. No mention of the find was made in British archaeological circles or the local Sussex or national press at the time of discovery, and neither Chichester District Museum nor the district or county based Sites and Monuments Record / Historic Environment Record has any record of it. ${ }^{72}$ As a consequence the portrait is entirely absent from any discussion concerning the art or archaeology of Roman Britain. ${ }^{73}$
\end{abstract}

\title{
DESCRIPTION (FIG. 9)
}

The portrait, comprising the head and upper torso of a bearded man clad in tunica and toga, measures $401 \mathrm{~mm}$ in height and is $312 \mathrm{~mm}$ wide. The head is large and out of proportion when compared with the torso. The hair is combed forwards, without a parting, from the crown to the face, and slight sideburns flick out over the ears. Individual locks are simply defined with deep incisions, sweeping vertically downwards at the back of the right side of the head, less realistically in diagonal strands over the ear and down around the neck on the left side. The arching fringe is heavy and low across the forehead, locks curling slightly from right to left until they reach the right side of the right eye. The coiffure tapers slightly at the nape of the neck, terminating in a well defined horizontal line just below the ears. Beard and moustache are full face and closely trimmed around the mouth, the moustache covering the entirety of the upper lip. Lightly scored incisions in the beard suggest

Levi 1944; Luce and Hencken 1945, 367-8; Padgett 2001, 80-2.

Accession number: y1943-90.

J. Michael Padgett, pers. comm. 2011.

Levi 1944, 9; Luce and Hencken 1945, 367; Padgett 2001, 82.

James Kenny, pers. comm. 2011; Mark Taylor, pers. comm. 2011.

For example, Toynbee 1962; 1964; Cunliffe and Fulford 1982; Henig 1995; Russell 2006. 

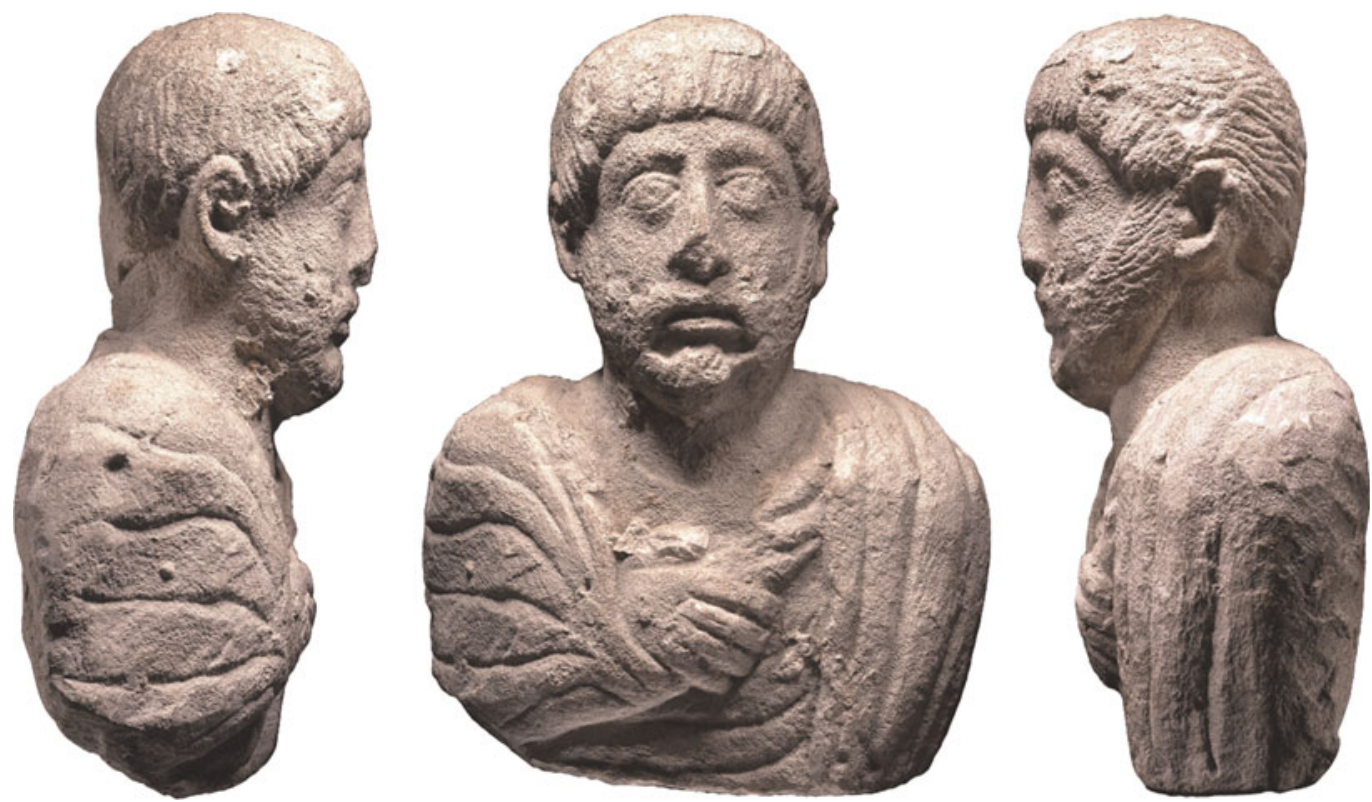

FIG. 9. The Chichester togatus: front view and profiles. (Photo: courtesy of J. Michael Padgett; (C) The Art Museum, Princeton University)

individual tufts of hair sprouting in downward sloping, parallel bands from beneath the sideburns to the chin. Slight damage to the chin has unfortunately removed the lowermost part of the beard.

The head is set low on a short and shapeless neck, which, when combined with the rounded shoulders, creates a slightly hunched appearance in the figure. The face is largely expressionless, the deeply-carved mouth, defined by the lower lip, being sharply turned down at the corners establishing a 'very severe air' ${ }^{74}$ The outer edges of the disproportionately large, ovate eyes sit at a lower level in the face than the inner corners, mirroring, together with the sharply-arched eyebrows, the mournful downward slope of the mouth. Eyelids are defined by rounded furrows, the shallow eyes themselves possessing lightly drilled pupils and incised irises. The broadly triangular, flat nose is simply rendered, the tip having been lost in antiquity. The large and slightly detached, protruding ears are highly stylised.

The toga is worn in traditional style, slung around the body and over the left shoulder and arm, the right hand emerging from the garment. The shortened arm is unrealistically depicted, with the elbow rounded off and toga folds converging upon the wrist. The exposed hand is thoroughly lacking in any anatomical detail, with four flat and rather stubby fingers apparently grasping folds of clothing across the left breast, the thumb being lost within the garment. It is just possible that the hand may have been grasping a scroll or legal document (such as a will), something which would strengthen the argument that the portrait was in some way funerary (see below). However, since the item being clasped clearly disappears into the folds of the toga portrayed over the left shoulder, it is probably more likely that this was intended to represent an area of clothing.

The image seems to have been designed to be viewed from the front, with the detail at the rear being very poorly realised, and the face and overall body profile appearing flat and narrow. The toga is crudely represented; individual folds are depicted with coarse and deeply scored parallel grooves which extend over the shoulders to the back, where they are only roughly finished. The rounded nature of the base 
suggests that the dimensions of the portrait were constrained by the size of the original stone and that the statue was never intended to be full-figure.

The back of the neck and parts of the lower torso have been damaged, possibly during initial recovery in the early 1900s. The comparatively 'fresh' nature of the carving, as evident in the toga and face, may indicate that the statue had not been exposed much to the elements prior to burial. Two holes in the back of the portrait and a dowel hole within the roughly finished base may further indicate original mounting points, suggesting that the bust had been fitted either to a plinth or column or alternatively to the base of an alcove.

\section{GEOLOGY}

The sculpture, as first established in the 1943 record of Frances Follin Jones, is made from chalk. There are at least two examples of funerary monuments from Roman Britain carved from a particularly hard French dolomitic chalk; namely a tombstone from High Holborn in London, found in $1961,{ }^{75}$ and the so-called 'Richborough Lion', reused as building material in the third century A.D. ${ }^{76}$ Calcaires Polypiers, a white, powdery, coral-rich limestone derived from the area of Norroy-lès-Pont-à-Mousson in North-Eastern France, and sometimes mistaken for chalk, has been identified as the source for numerous first-century military monuments along the Rhine and in the tombstone of Marcus Favonius Facilis at Colchester,77 whilst Calcaires Grossier, another French limestone characterised by tiny ditrupa (worm tubes), has been found in some first-century Roman contexts at both Chichester and Fishbourne. ${ }^{78}$

A sample of the statue has been examined by the Department of Geosciences at Princeton University and the following report produced:

A thin section of a chip taken from the inward surface of the bust yields the following evidence as to the nature and source of the material. (1) The material is such that it could not have come from any known occurrence in the Mediterranean region. (2) It would appear to have come from certain strata of the chalk of Cretaceous Age as exposed and quarried from prehistoric times to the present in the Paris Basin which, stratigraphically, is well exposed on both sides of the English Channel. (3) Microscopic examination also proves that the material is in its natural state, except for a natural chemical alteration (weathering) of the surface, and the bust, therefore, was not carved from a cement block made from the Cretaceous chalk, but a partially cemented, coarse grained chalk rich in sponge spicules. ${ }^{79}$

The statue would appear to have been created from a harder wearing variety of chalk known as Lavant Stone, ${ }^{80}$ a layer found in the Upper Chalk and confined to a relatively small area just north of Chichester. It is a light-coloured, partially cemented, coarse-grained, phosphatic chalk which, as with the Princeton portrait, is rich in microscopic sponge spicules. Because of its relatively good weather resistance, Lavant Stone was acquired for use in a number of prestigious later Roman and early medieval building projects across Sussex and eastern Hampshire, ${ }^{81}$ examples of the material being noted in third-century building work at the villas of Bignor and Chilgrove (where it was used for internal columns and decorative work) and also from the public baths of Roman Chichester. ${ }^{82}$ The stone may have had only local significance, for no examples are known from Roman contexts beyond a distance of $18 \mathrm{~km}$ from the primary outcrop and suggested quarry zone. A large quantity of Lavant Stone was used during thirteenth-century building work at Chichester cathedral, although mostly in areas hidden from public view and never in direct contact with the ground. The largest individual piece, measuring in excess of $1.9 \mathrm{~m}$ in length, is recorded

Hayward 2009, 140-1.

Hayward 2009, 158; Hayward, pers. comm. 2012.

Hayward 2006, 360; 2009, 133-4.

Hayward 2009, 154-5.

I am grateful to J. Michael Padgett, Curator of Ancient Art at the Art Museum, Princeton University for a copy of the geological report.

80 Bone and Bone 2000.

81 Bone and Bone 2005.

82 Bone and Bone 2005, 67-9. 
from the footings of the Lady Chapel of the cathedral. ${ }^{83}$ Use of the material seems to have died out by the fourteenth century, possibly when the source became exhausted.

\section{DATE}

The overall artistic execution of the bust, in particular the rather crudely depicted toga, disproportionately large head and elongated eyes, when combined with the material used in construction, indicates that the statue was produced locally, rather than representing a foreign import. There is some similarity between the face of the Chichester bust and the rather 'doleful expressions' of better known provincial sculptured forms whose 'conception is Mediterranean, but not the bold outlining of the bulging eyes' ${ }^{84}$ Good examples of native execution may be seen in the drooping mouth and other-worldly, elongated eyes of a larger than life-size female head from Towcester, ${ }^{85}$ a female head from Birrens, ${ }^{86}$ and the famous gorgon pediment from Bath. ${ }^{87}$ This distinctive form of portrait typology, created from the symbiosis between Mediterranean ideas and indigenous style, has been much commented upon ${ }^{88}$ and has appropriately been referred to as interpretatio romana. ${ }^{89}$ Such vigorous native/'Celtic' (or at least 'north-west provincial') forms permeate the Romano-British period, but do not in themselves provide much of a clue with regard to dating. The Bath pediment, for example, seems to have been part of a later first-century A.D. temple façade, whilst the Towcester and Birrens heads cannot be dated anymore firmly than the second to fourth century.

The pose taken by the Chichester bust, with the right hand grasping the folds, evokes the late republican togate formality of a kind seen little in official imperial portraits after the early first century A.D. ${ }^{90}$ The sculpture could, therefore, be relatively early, the city of Noviomagus having been established by at least A.D. 58. ${ }^{91}$ The presence of luxuriant beard and drilled eyes (especially the pupils) would, however, at the very least indicate an execution date in the second or third century, whilst it has been noted that the 'arching brow reiterated by the hairline' evokes portraits of the fourth century, and comparisons can been made with late Western emperors such as Gratian ${ }^{92}$ and Julian, ${ }^{93}$ whilst the fringe and beard are also reminiscent of figures from the early fourth-century Arch of Constantine in Rome. ${ }^{94} \mathrm{~A}$ creation somewhere in the later third to fourth century A.D. seems to be an acceptable, if rather chronologically broad, compromise for the Chichester statue. Sculpture from this period is rare in Britain, ${ }^{95}$ although the monumental portrait in marble of a clean-shaven emperor (probably Constantine the Great) from York ${ }^{96}$ shows that sculptors were 'evidently still operating in the $4^{\text {th }}$ century'. ${ }^{97}$

\section{CONTEXT}

Despite the lack of contemporary reporting of the statue in Britain, it is possible to provide some degree of context for the piece. Unfortunately, there is no specific record of a 'Wycombe' House ${ }^{98}$ in Chichester during

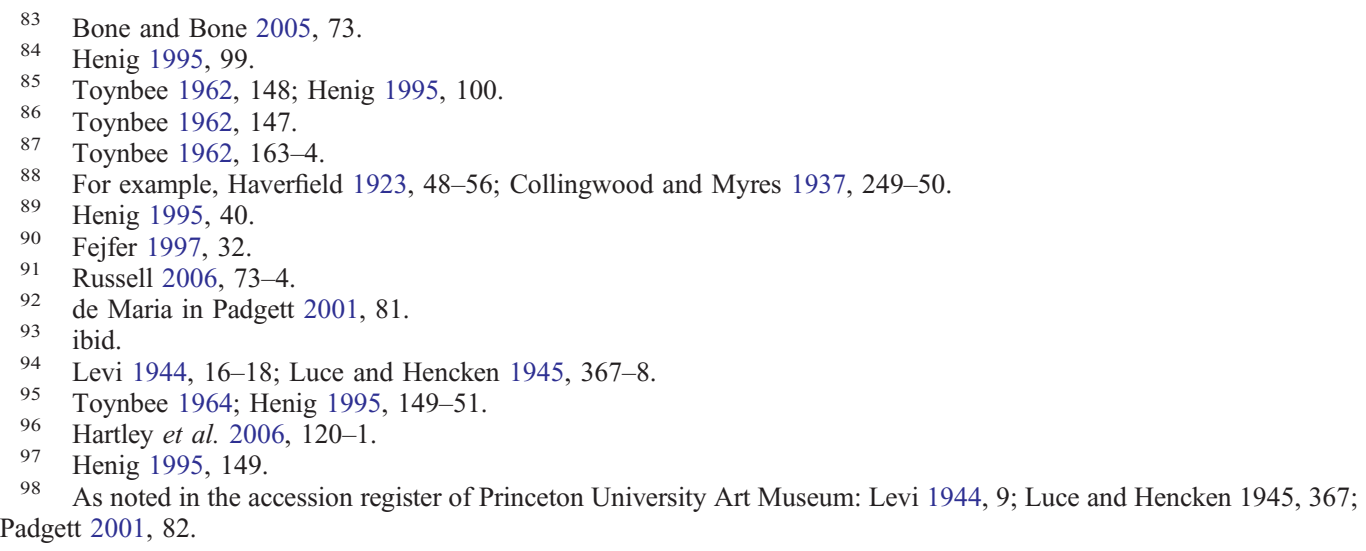


the early years of the twentieth century, when the bust was supposedly found. It is, however, worth noting that the area of Chichester now known as Whyke, was largely developed in the mid-nineteenth century ${ }^{99}$ and was, for a brief period at least, known as 'Wickham'. ${ }^{100}$

Wickham, or Whykeham, first appears as 'Wiche' in the Domesday Book of 1086, and was, until the mid-nineteenth century, a relatively small village, with occupation clustering around St Mary's church.101 The area is referred to as 'Rumboldswhyke' on maps from the eighteenth century onwards, although the precise derivation of this particular name is unknown. The character of the village changed little until the arrival of the railway, connecting Chichester to Brighton, in 1846, whereupon there was a rapid expansion in housing and commercial development. Among the buildings established here were a number of high status houses, one of which is named on the 1875 Ordnance Survey as 'Whykeham Lodge'. ${ }^{102}$ By 1893, Rumboldwhyke was formally incorporated within the area of Chichester City Corporation, whereupon it seems to have reverted to the simpler form of 'Whyke', which it still retains. None of the house names, or indeed that of Wickham Road itself (now York Road), appear on the 1898 OS map, and only that of the public house, the Wickham Arms survives to this day. As there was a 'Whykeham Lodge' there may well have been a 'Whykeham' or 'Wycombe' House in the immediate area. It is, of course, entirely possible that the 'Lodge' and 'House' were in fact one and the same, the finds details becoming corrupted (or mistranscribed) in the intervening years between the initial discovery, transference to art dealer Joseph Brummer and final sale to the Art Museum of Princeton University. In such a scenario, Whykeham Lodge could easily have mutated into the 'Wycombe House' of Frances Follin Jones' acquisition record.

The area that was to become Whyke/Wickham lay to the south-east of the Roman town of Noviomagus, outside the city walls. Unless there was a major, as yet undiscovered, Romano-British building complex in the immediate vicinity, the portrait bust may well originally have been funerary, set up within one of the extramural cemeteries recorded outside the northern, eastern, western and (possibly) southern gates. ${ }^{103}$ Little is known with regard to the nature of surface furniture set up within these cemeteries, although the partial fragments of three tombstones have to date been recovered, recycled as building stone in the later third-century walls of the city. ${ }^{104}$ As a free-standing bust, however, the Chichester portrait may appear an unusual addition to a Romano-British cemetery where long-term exposure to the elements would certainly have caused far more extensive weathering and surface erosion than is evident on the piece today.

Alternatively, the bust may have derived from within the city of Noviomagus itself, being brought to what was to become Wickham in the post-Roman period, either as a curio or as a solid piece of reusable building material. If the intention was to reuse the piece, however, there is no sign of reshaping, modification or mortar attachment. It is worth noting, in respect of monumental artwork recovered from Chichester, that Noviomagus and its hinterland were certainly not short of inscriptions and imperial statuary, although much of this material is of mid- to later first-century date. The town can boast inscriptions to Nero and the client king Tiberius Claudius Togidubnus, ${ }^{105}$ whilst depictions in marble of a boy, a youthful member of the imperial family (possibly either Germanicus or Gaius) and a monumental image of the emperor Trajan have been recovered from sites to the south and immediate west. ${ }^{106}$

It is possible that the Chichester portrait represents a product of the 'Grand Tour', having been acquired in the eighteenth or nineteenth century from continental Europe before being buried or otherwise discarded at the rear of Whykeham Lodge (possibly after use as a garden ornament). The somewhat battered, 'unclassical' form of the bust when combined with the observation that it was manufactured from cretaceous chalk (rather than the more desirable Mediterranean marble), however, makes it unlikely that the artefact represents a recent import such as may be seen in the collection of Charles Wyndham

99 Before the Ordnance Survey first edition of 1875.

100 Katherine Slay, pers. comm. 2012.

101 Katherine Slay, pers. comm. 2012.

102 James Kenny, pers. comm. 2011.

103 Down and Rule 1971; Down 1988; Down and Magilton 1993; Hayden 2011.

104 Russell 2006, 93-5.

105 RIB I, 91 and 92; Bogaers 1979, 243-54; Russell 2006, 35-7, 45-51, 72-4.

106 Painter 1965; Soffe and Henig 1999; Russell 2006, 106-13, 214-19. 
(1710-63), 2nd Earl of Egremont, in nearby Petworth House. ${ }^{107}$ It may also be argued that, aside from the obvious lack of association of the portrait with a country seat or great collecting estate, the piece is not so well preserved as to have perhaps warranted costly transportation back to Britain from a putative continental findspot. In short, its Romano-British credentials would appear to be secure.

\section{IDENTITY}

Given the overtly stylised form of the portrait, there is perhaps little that can be said with regard to identity. That he was a Roman citizen seems clear enough, given the extravagant use of toga and formal republican-style pose. The piece could, of course, represent a third- or fourth-century emperor, regional administrator or usurper. An imperial portrait is a possibility, and comparisons have previously been drawn with the emperors Gratian and Julian. ${ }^{108}$ The arrangement of fringe and beard is certainly reminiscent of Julian, who was, it should be noted, militarily active in the North-Western provinces during the late A.D. 350s and early 360s. As a locally produced likeness of Julian, the bust could plausibly have been designed to sit within a prominent civic building, only to be quietly removed following the emperor's death in A.D. 363. The relatively unimpressive (non-monumental) size of the portrait, however, may argue against an overtly imperial association. Tempting though it is to find identity within the list of bearded emperors with a specific link to Britain, ${ }^{109}$ or, indeed, with a series of historically attested rebels, ${ }^{110}$ the largely unrealistic nature of the portrait means that an exact identification will probably remain impossible.

The bust could, on the other hand, plausibly represent a portrait of an important local dignitary or city benefactor - an honorific statue with which to glorify the achievements of a particular individual. Discoveries of non-imperial portraits are rare in Britain, but examples may be cited from Caerwent, where the base for such a statue, erected in the second decade of the third century to commemorate Tiberius Claudius Paulinus, has been found ${ }^{111}$ and Lullingstone, where two late second- or early third-century portrait busts, possibly of former landowners (although a plausible case has been made for the emperor Pertinax and a member of his family) were discovered buried in the cellar of a villa. ${ }^{112}$ The lost statue from Caerwent may represent a useful parallel, for Paulinus, commander of Legion II Augusta, went on to become proconsular governor of Narbonensis and governor of Britannia Inferior. He was, therefore, 'a locally based aristocrat with extraordinary influence in Rome and other provinces'113 and the ordo of the civitas of the Silures who dedicated the statue evidently had an eye to their own future economic and political prosperity. The Chichester portrait could conceivably represent a similar attempt by the ordo of Noviomagus to glorify a prominent local or more international political figure. The form of the Sussex portrait, however, suggests that it was not originally intended as a full-figure statue, more a crudely worked herm, and it may therefore have more in common (in intent rather than style) with the Lullingstone busts, which were probably revered privately as family or ancestral likenesses.

Whoever the Chichester bust was originally intended to represent, and whatever its precise context within the city of Noviomagus, it remains an exciting and hugely important find: a 'new' piece of later Romano-British art quite possibly depicting a Roman citizen of Britannia. Hopefully it may now take its place in the catalogue of provincial artwork recovered from the British Isles.

107 Raeder 2000.

108 de Maria in Padgett 2001, 81-2.

109 Such as Hadrian (A.D. 117-38), Antoninus Pius (A.D. 138-61), Pertinax (A.D. 193), Septimius Severus (A.D. 193211), or Caracalla (A.D. 198-217).

110 Such as Clodius Albinus (A.D. 193-7), Postumus (A.D. 260-9), Victorinus (A.D. 269-71), Tetricus I (A.D. 271-4), Carausius (A.D. 286-93), or Allectus (A.D. 293-6).

111 RIB I, 311.

112 Toynbee 1964, 59-63.

113 Stewart 2003, 179. 


\section{ACKNOWLEDGEMENTS}

I am immensely grateful to J. Michael Padgett, Curator of Ancient Art at the Art Museum, Princeton University for his help at all stages of compiling this short report and for allowing me to reproduce pictures of the Chichester bust and to Katherine Slay, Archives Assistant (Collections Cataloguing), West Sussex Record Office for her help in establishing information concerning the development of Whyke and Whykeham Lodge. I would also like to thank David and Anne Bone, Richard Brewer, Kevin Hayward, Martin Henig, James Kenny, John Mills, Mark Taylor and the two anonymous referees for their helpful comments and advice.

\section{School of Applied Sciences, Bournemouth University}

mrussell@bournemouth.ac.uk

doi:10.1017/S0068113X13000263

\section{BIBLIOGRAPHY}

Bogaers, J. 1979: 'King Cogidubnus in Chichester: another reading of RIB 91', Britannia 10, 243-54

Bone, D., and Bone, A. 2000: 'Lavant Stone: a late Roman and medieval building stone from the Chalk (Upper Cretaceous) of West Sussex', Proceedings of the Geologists' Association 111, 193-20

Bone, A., and Bone, D. 2005: 'Lavant Stone: a Roman and medieval building stone in West Sussex', Sussex Archaeological Collections 142, 63-78

Collingwood, R., and Myres, J. 1937: Roman Britain and the English Settlements (2nd edn), Oxford

Cunliffe, B., and Fulford, M. 1982: Corpus Signorum Imperii Romani, Great Britain I, 2, Bath and the Rest of Wessex, Oxford

Down, A. 1988: Roman Chichester, Chichester

Down, A., and Magilton, J. 1993: Chichester Excavations 8, Chichester

Down, A., and Rule, M. 1971: Chichester Excavations 1, Chichester

Fejfer, J. 1997: The Ince Blundell Collection of Classical Sculpture. Volume I - The Portraits. Part 2: The Roman Male Portraits, Liverpool

Hartley, E., Hawkes, J., Henig, M., and Mee, F. 2006: Constantine the Great: York's Roman Emperor, York Haverfield, F. 1923: The Romanization of Roman Britain (4th edn), Oxford

Hayden, G. 2011: 'Dialogues in deposition: a reassessment of early Roman-period burials at St Pancras, Chichester, and other related sites', Sussex Archaeological Collections 149, 35-48

Hayward, K. 2006: 'A geological link between the Facilis monument at Colchester and first-century army tombstones from the Rhineland frontier', Britannia 37, 359-63

Hayward, K. 2009: Roman Quarrying and Stone Supply on the Periphery - Southern England: A Geological Study of First Century Funerary Monuments and Monumental Architecture, BAR British Series 500, Oxford

Henig, M. 1995: The Art of Roman Britain, London

Levi, D. 1944: 'A chalk bust from Chichester', Record of the Museum of Historic Art, Princeton University $3.2,9-18$

Luce, S., and Hencken, H. 1945: 'Archaeological news and discussions', American Journal of Archaeology 49.3 (July-Sept.), 358-77

Padgett, J. 2001: Roman Sculpture in the Art Museum, Princeton University, Princeton

Painter, K. 1965: 'A Roman marble head from Sussex', Antiquaries Journal 45, 178-82

Raeder, J. 2000: Die antiken Skulpturen in Petworth House (West Sussex), Mainz am Rhein

RIB I: R.G. Collingwood and R.P. Wright, The Roman Inscriptions of Britain, I: Inscriptions on Stone (1965)

Russell, M. 2006: Roman Sussex, Stroud

Soffe, G., and Henig, M. 1999: 'Roman marble and bronze sculpture in the kingdom of Togidubnus', Association for Roman Archaeology Bulletin 8, 8-10

Stewart, P. 2003: Statues in Roman Society: Representation and Response, Oxford

Toynbee, J. 1962: Art in Roman Britain, London

Toynbee, J. 1964: Art in Britain under the Romans, Oxford 